\title{
ANALYSIS OF ANC LEVELS AFTER FILGRASTIM THERAPY IN ACUTE LEUKEMIA CHILDREN WITH NEUTROPENIA
}

\author{
Reta Anggraeni Widya ${ }^{1}$, Susanto Nugroho², Sri Winarsih ${ }^{3}$, Yulistiani ${ }^{1}$ \\ ${ }^{1}$ Master Program of Clinical Pharmacy, Universitas Airlangga, Surabaya, ${ }^{2}$ Department of Pediatrics, Nephrology \\ Division, ${ }^{3}$ Pharmacy Installation of Dr. Saiful Anwar Teaching Hospital, Malang, Indonesia
}

\begin{abstract}
Cytotoxic chemotherapy suppresses the hematopoietic system, and the most serious hematologic toxicity is neutropenia. This can decrease a risk of infection that causes delays in treatment and reduction of dose intensity, which reduces therapeutic outcome. Filgrastim is used to increase neutrophils level whose therapeutic effect is unknown. The effectiveness of filgrastim is based on the ANC level pre-and post-therapy. This study aimed to analyze the use of filgrastim on ANC level changes in acute leukemia children with neutropenia, and to analyze the patient that achieve ANC level's targeted therapy $=1000 \mathrm{cell} / \mathrm{mm}^{3}$. A prospective observational study with a longitudinal design was conducted from June to October 2016. The inclusion criteria of the study were patients who diagnosed acute leukemia with neutropenia and received filgrastim $10 \mu \mathrm{g} / \mathrm{kgBW}$ for 3, 4, 5 days. Patients' ANC levels were measured before and after filgrastim therapy. This study has been approved its ethical clearance by Dr. Saiful Anwar Hospital, Malang. Data were obtained on the basis of neutropenic episodes, followed by 7 episodes of obtaining filgrastim for 3 days, 1 episode of obtaining filgrastim for 4 days, and 7 episodes of obtaining filgrastim for 5 days. Thus, it consists of 15 episodes. In 3 days, ANC levels increased by 9.5 fold from $381.3 \pm 91.8 \mathrm{cell} / \mathrm{mm}^{3}$ to $3984.9 \pm 426.8 \mathrm{cell} / \mathrm{mm}^{3}$, but in 5 days, ANC levels decreased by 0.9 fold from $200.9 \mathrm{cell} / \mathrm{mm}^{3} \pm 98.2$ to $189.7 \pm 14.2 \mathrm{cell} / \mathrm{mm}^{3}$. Filgrastim was able to increased the ANC levels around nine fold for 3 days of theraphy. There were 53\% neutropenia patients who achieved the goal of therapy. Filgrastim therapy with dose 10 $\mu \mathrm{g} / \mathrm{kgBW}$ for 3 to 5 days has been able to reach the therapeutic target of 53\% in acute leukemia children with neutropenia. The increased levels of ANC maximum was reached on the third day with increased levels of 9.5 fold.
\end{abstract}

Keywords: Filgrastim; absolute neutrophyl count (ANC); acute leukemia; chemotherapy induce neutropenia (CIN)

\section{ABSTRAK}

Kemoterapi sitotoksik menekan sistem hematopoietik, dan toksisitas hematologis paling serius adalah neutropenia. Ini dapat mengurangi risiko infeksi yang menyebabkan keterlambatan dalam perawatan dan pengurangan intensitas dosis, yang mengurangi hasil terapi. Filgrastim digunakan untuk meningkatkan kadar neutrofil yang efek terapeutiknya tidak diketahui. Efektivitas filgrastim didasarkan pada tingkat sebelum dan sesudah terapi ANC. Penelitian ini bertujuan untuk menganalisis penggunaan filgrastim pada perubahan level ANC pada anak-anak leukemia akut dengan neutropenia, dan untuk menganalisis pasien yang mencapai terapi target level $A N C=1000 \mathrm{sel} / \mathrm{mm}^{3}$. Sebuah studi observasional prospektif dengan desain longitudinal dilakukan dari Juni hingga Oktober 2016. Kriteria inklusi dari penelitian ini adalah pasien yang didiagnosis leukemia akut dengan neutropenia dan menerima filgrastim 10 ug/kgBB selama 3, 4, 5 hari. Pasien diukur kadar ANC sebelum dan sesudah terapi filgrastim. Penelitian ini telah disetujui izin etisnya oleh Rumah Sakit Pendidikan Dr. Saiful Anwar Malang. Data diperoleh berdasarkan episode neutropenik, diikuti 7 episode diambil filgrastim selama 3 hari, 1 episode diambil filgrastim selama 4 hari, dan 7 episode diambil filgrastim selama 5 hari, sehingga terdiri dari 15 episode. Dalam 3 hari, tingkat ANC meningkat 9,5 kali lipat dari 381,3 \pm 91,8 sel/mm ${ }^{3}$ menjadi 3984,9 $\pm 426,8 \mathrm{sel} / \mathrm{mm}^{3}$, tetapi dalam 5 hari, tingkat ANC menurun 0,9 kali lipat dari 200,9 $\pm 98,2 \mathrm{cell} / \mathrm{mm}^{3} \mathrm{menjadi} 189,7 \pm$ $14,2 \mathrm{cell} / \mathrm{mm}^{3}$. Filgrastim mampu meningkatkan kadar ANC sekitar sembilan kali lipat selama 3 hari terapi. Ada 53\% pasien neutropenia yang mencapai tujuan terapi. Terapi filgrastim dengan dosis $10 \mu \mathrm{g} / \mathrm{kgBB}$ selama 3 hingga 5 hari, telah mampu mencapai target terapi $53 \%$ pada anak leukemia akut dengan neutropenia. Peningkatan level maksimum ANC tercapai pada hari ketiga dengan peningkatan level 9,5 kali lipat.

Kata kunci: Filgrastim; jumlah neutrofil absolut (ANC); leukemia akut; kemoterapi menginduksi neutropenia (CIN)

Correspondence: Reta Anggraeni Widya, Master Program of Clinical Pharmacy, Universitas Airlangga, Surabaya, Indonesia. E-mail: retaawidya@gmail.com

pISSN:2355-8393 • eISSN: 2599-056x • doi: http://dx.doi.org/10.20473/fmi.v55i1.12543

- Fol Med Indones. 2019;55:10-16 • Received 9 Feb $2017 \bullet$ Accepted 20 Jul 2017

- Open access under CC-BY-NC-SA license • Available at https://e-journal.unair.ac.id/FMI/ 


\section{INTRODUCTION}

Acute leukemia is a group of malignant diseases where genetic abnormalities in hematopoietic cells lead to unregulated clonal cell proliferation (Tubergen et al 2016). Acute leukemia accounts for approximately $97 \%$ of cases of childhood leukemia. In development country the incidence of acute myelogenous leukemia (AML) is approximately $17 \%$ and acute lymphoblastic leukemia (ALL) is $83 \%$. In Dr. Soetomo Hospital, throughout the 2002 there were $885 \mathrm{ALL}, 85 \mathrm{ML}$ and $4 \%$ chronic leukemia of 70 new cases of leukemia (Permono et al 2010). Chemotherapy is the main therapy in leukemia. Neutropenia and its complications, including febrile neutropenia, are major toxicities related to myelosuppressive systemic cancer chemotherapy. This can decrease a risk of infection that causes delays in treatment and reduction of dose intensity, which reduces therapeutic outcome (Hansen et al 2010, Bracci et al 2014).

Human granulocyte colony-stimulating factor (GCSF) is a hematopoietic hormone that have been shown to reduce the duration and severity of neutropenia and the risk of febrile neutropenia. GCSF promotes the growth, proliferation, differentiation, and maturation of neutrophil precursors (Crawford et al 2010). The first generation of GCSF pharmaceuticals, which recombinant derivatives, is Filgrastim (nonglycosylated) (Scholz et al 2012).

As a result of extensive investigations, risk of neutropenia and febrile neutropenia in patients receiving myelosuppressive chemotherapy were generally lower for prophylaxis with filgrastim (Ghalaut et al 2008, Rosary 2010, Lyman et al 2013, Mitchell et al 2016). However, some research showed different results, according to several that showed the use of filgrastim in severe neutropenia induced chemoteraphy is not recommended, because there is no significant difference between the ANC increase in patients using placebo and filgrastim (Rodriguez et al 2005, Velasco 2010).

The use of therapeutic filgrastim in patients with established fever and neutropenia is controversial. In developing countries, as well as in Dr. Saiful Anwar Hospital, Malang, filgrastim given as a therapy for neutropenia induced chemotherapy. The use of filgrastim for prophylaxis is difficult because the price is pretty expensive. The purpose of this study was to analyze the use of filgrastim on ANC levels changes in acute leukemia children with neutropenia, and the patient that achieve ANC level's targeted therapy = $1000 \mathrm{cell} / \mathrm{mm}^{3}$.

\section{MATERIALS AND METHODS}

This study used a prospective observational with a longitudinal design from June to October 2016 at Paediatric Departement, Hematology Division of Dr. Saiful Anwar Hospital, Malang. The inclusion criteria was children aged $<18$ years who diagnosed acute leukemia with neutropenia, who had received filgrastim of $10 \mu \mathrm{g} / \mathrm{kgBW}$ for $3,4,5$ days, then ANC level measurement was carried out before and after filgrastim induction. This study excluded the patients who were sensitive of filgrastim, and used filgrastim for prophylaxis.

The effects and therapeutic use of filgrastim were explained at the beginning of the study. A standard medical history, clinical, and laboratory data were collected from patient information and based on medical record. The ANC was calculated from the differential leukocyte count (performed manually) and the absolute number of leucocytes (performed automatically using a Coulter counter (Sysmex NE-8000, Tao Medical Electronics, Kobe, Japan)). The ANC was measured with flow cytometry method. This study was approved by the Ethics Committee of the Dr. Saiful Anwar Hospital, Malang.

Nominal scale data were described as frequency distribution and interval scale data were described as mean, deviations standard, and medians. Data analysis was started with normality test with Shapiro Wilk. A comparative hypothesis test was performed to determine differences ANC levels between 3 and 5 days in filgrastim therapy with Paired Samples T-Test, and differences ANC levels each day with One Way Anova. The test results were statistically significant if probability (p) $<0.05$ with a confidence interval of $95 \%$.

\section{RESULTS}

Table 1 shows the baseline characteristics of patients. Twelve children were recruited for the study. The majority of children with neutropenia were female with age 0-6 years. Female displayed a higher risk for neutropenia than male. 


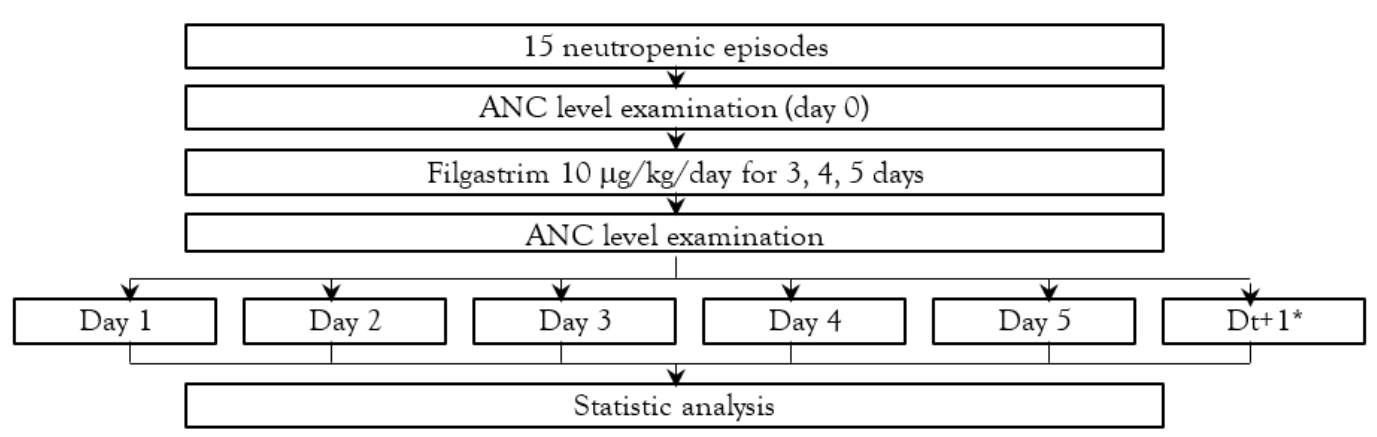

Fig. 1. Dt+1 is 24 hours of filgrastim discontinuity.

Table 1. Baseline characteristics of patients

\begin{tabular}{|c|c|c|c|}
\hline \multicolumn{2}{|c|}{ Patients' Characteristics } & $\begin{array}{c}\text { Total Patients }(\mathrm{N}=12) \\
\mathrm{n}(\%)\end{array}$ & Mean (SD) \\
\hline \multirow[t]{2}{*}{ Gender } & Boys & $5(42)$ & - \\
\hline & Girls & $7(58)$ & - \\
\hline \multirow[t]{2}{*}{ Age } & $0-6$ years & $8(67)$ & $3.4(1.1)$ \\
\hline & $7-12$ years & $4(33)$ & $10.2(1.0)$ \\
\hline \multirow{2}{*}{$\begin{array}{l}\text { Type of acute } \\
\text { leukemia }\end{array}$} & ALL & $4(33)$ & - \\
\hline & AML & $8(67)$ & - \\
\hline \multirow{2}{*}{$\begin{array}{l}\text { Neutropenic } \\
\text { episodic }\end{array}$} & Once & $9(75)$ & - \\
\hline & Twice & $3(25)$ & - \\
\hline \multirow[t]{3}{*}{ Filgrastim therapy* } & 3 days & $7(46.7)$ & - \\
\hline & 4 days & $1(6.6)$ & - \\
\hline & 5 days & $7(46.7)$ & - \\
\hline \multirow[t]{3}{*}{ Filgrastim Dose/kg } & $<10 \mu \mathrm{g}$ & $2(16.7)$ & $9.3(0.7)$ \\
\hline & $10 \mu \mathrm{g}$ & $2(16.7)$ & $10(0.0)$ \\
\hline & $>10 \mu \mathrm{g}$ & $8(66.6)$ & $11.7(1.1)$ \\
\hline \multirow{2}{*}{$\begin{array}{l}\text { Leukosit levels } \\
\text { (cell/mm3) }\end{array}$} & $>4000$ & $1(8.3)$ & $5782(0.0)$ \\
\hline & $<4000$ & $11(91.7)$ & $1413.5(1152.6)$ \\
\hline \multirow{3}{*}{$\begin{array}{l}\text { ANC levels } \\
\text { (cell/mm3) }\end{array}$} & $>1000$ & 0 & - \\
\hline & $1000-500$ & $2(16.7)$ & $615.5(54.8)$ \\
\hline & $<500$ & $10(83.3)$ & $173.5(98.2)$ \\
\hline \multirow[t]{3}{*}{ Complication } & Neutropenia & $5(41.7)$ & - \\
\hline & Febrile neutropenia & $3(25)$ & - \\
\hline & $\mathrm{FN}+$ another comorbid & $4(33.3)$ & - \\
\hline
\end{tabular}

Table 2 shows ANC level changes in acute leukemia with neutropenia patients in which 7 episodes took filgrastim for 3 days, 1 episode took filgrastim for 4 day, and 7 episodes took filgrastim for 5 days. Thus, it consisted of 15 episodes. During the 5-days dosing period and the 1 postdosing day in which ANC was measured, daily ANC value showed persistent increase over the first 3-days dosing period and decreased sharply on days 4 and 5 . On day 1, the ANC levels increased $82.2 \%$ and reached a maximum level in 3 days. The ANC levels decreased $87.2 \%$ on day 4. ANC levels decreased by $4.2-43.1 \%$ within 24 hours of filgrastrim discontinuity.
In 3 days therapy of filgrastim, ANC levels increased by 9.5 fold from $381.3 \pm 91.8 \mathrm{cell} / \mathrm{mm}^{3}$ to $3984.9 \pm 426.8$ cell $/ \mathrm{mm}^{3}$. The ANC levels increased by 13.5 fold in 4 days therapy, but decreased by 0.9 fold in 5 days therapy. Filgrastim had increased the ANC levels unsignificanly in neutropenia patients. There were 53\% neutropenia patients who achieved the goal of therapy.

\section{DISCUSSION}

In this study, most patients had ANC levels under 500 cells $/ \mathrm{mm}^{3}$ (severe neutropenia) before given with filgrastim therapy. It appears that the episodes of neutropenia may occur due to infiltration of malignant 
cells in the bone marrow or due to the impact of myelosuppresive chemotherapy (Pertiwi et al 2013, Sudewi et al 2007). Furthermore, the guidelines recognize that older age (particularly >65 years), previous chemotherapy or radiotherapy, pre-existing neutropenia or tumor involvement in the bone marrow, poor performance status, comorbidities (e.g., renal or liver dysfunction), and pre-existing conditions (e.g., infection) are risk factors for developing severe neutropenia (Lyman et al 2014). Neutropenia is more common in females than males, the differences in total bone mass might explain the lower incidence of neutropenia seen in males. Greater marrow volume (as would be expected with men) might provide an individual with the ability to better tolerate chemotherapy and/or respond to an exogenous myeloid growth factor (Crawford et al 2005, Lyman et al 2014).

Severe neutropenia may be complicated by fever or febrile neutropenia. In this study about $58 \%$ patients had febrile neutropenia. Fever may be a common presentation with some malignancies, and their progression may parallel the occurrence of fever. Although the exact mechanism of tumor-associated fever is unclear, it is thought to be involved with inflammatory cytokines, such as TNF- $\alpha$, IL-1, and IL-6, which are produced either by host macrophages in response to the tumor or by the tumor itself. These pyrogenic cytokines cause elevations in temperature by acting on the hypothalamic temperature setpoint (Dalal \& Zhukovsky 2006).

Table 2. ANC levels of patients

\begin{tabular}{|c|c|c|c|c|c|c|c|}
\hline \multirow{2}{*}{ Patient Code } & \multicolumn{7}{|c|}{ ANC levels (sel/mm3) } \\
\hline & Day 0 & Day 1 & Day 2 & Day 3 & Day 4 & Day 5 & $\mathrm{Dt}+1$ \\
\hline \multicolumn{8}{|c|}{3 Days Therapy Of Filgrastim $(\mathrm{Dt}=3)$} \\
\hline $\mathrm{A}(\mathrm{G}, 4 \mathrm{y})$ & 329.7 & 549.9 & 751 & 1209 & - & - & 1041 \\
\hline $\mathrm{DA}(\mathrm{B}, 4 \mathrm{y})$ & 680.2 & 2551.3 & 9247.5 & 14968 & - & - & 4492.8 \\
\hline RA1 (G, 4y) & 365 & 737 & 2547.1 & 3686.2 & - & - & 1780.5 \\
\hline $\mathrm{RI}(\mathrm{B}, 3 \mathrm{y})$ & 220.3 & 897 & 1378 & 2510 & - & - & 1789 \\
\hline RA2 (G, 4y) & 564 & 897 & 1103 & 3657 & - & - & 3045 \\
\hline $\mathrm{KH} 1(\mathrm{G}, 3 \mathrm{y})$ & 199.9 & 792 & 868.8 & 1812.6 & - & - & 1450 \\
\hline $\begin{array}{l}\mathrm{DY}(\mathrm{G}, \\
10 \mathrm{y}) * * *\end{array}$ & 309.6 & 437.9 & 261.2 & 52 & $\dagger$ & $\dagger$ & $\dagger$ \\
\hline $\begin{array}{l}\text { Mean } \pm \\
\text { SD }\end{array}$ & $381.3 \pm 14.2$ & $980.3 \pm 79.2$ & $\begin{array}{r}2308.1 \pm \\
346.3\end{array}$ & $\begin{array}{r}3984.9 \pm \\
818.1\end{array}$ & - & - & $2266 \pm 289.2$ \\
\hline$\% \Delta$ & & $\uparrow 157.1 \%$ & $\uparrow 135.4 \%$ & $\uparrow 72.7 \%$ & - & - & $\downarrow 43.1 \%$ \\
\hline \multicolumn{8}{|c|}{4 Days Therapy Of Filgrastim $(\mathrm{Dt}=4)$} \\
\hline NA2 (G, 3y) & 70.2 & 38.9 & 47.9 & 827 & 1021.2 & - & 978.1 \\
\hline$\% \Delta$ & & $\downarrow 44.5 \%$ & $\uparrow 23.14 \%$ & $\uparrow 1625.1 \%$ & $\uparrow 23.5 \%$ & - & $\downarrow 4.2 \%$ \\
\hline \multicolumn{8}{|c|}{5 Days Therapy Of Filgrastim $(\mathrm{Dt}=5)$} \\
\hline FF (B, 11y) & 10.1 & 19.8 & 30 & 39 & 38 & 40 & 37 \\
\hline $\mathrm{IA}(\mathrm{G}, 7 \mathrm{y})$ & 20.02 & 15.8 & 9.8 & 9.8 & 9.99 & 9.12 & 8.7 \\
\hline NA1 (G, 3y) & 390.4 & 326.4 & 389.9 & 190.8 & 677 & 1021.2 & 967 \\
\hline $\mathrm{J}(\mathrm{G}, 2 \mathrm{y})$ & 215 & 109 & 157.7 & 126 & 109 & 78.9 & 14 \\
\hline $\mathrm{MA}(\mathrm{B}, 2 \mathrm{y})$ & 602.6 & 92.6 & 95.8 & 99.2 & 102.2 & 118.6 & 99.9 \\
\hline $\operatorname{IR}(\mathrm{B}, 10 \mathrm{y})$ & 19.8 & 14.1 & 0 & 0 & 0 & 39.8 & 0 \\
\hline $\mathrm{KH} 2(\mathrm{G}, 3 \mathrm{y})$ & 149 & 119 & 109 & 79 & 45 & 19.9 & 10.5 \\
\hline $\begin{array}{l}\text { Mean } \pm \\
\text { SD }\end{array}$ & $200.9 \pm 98.2$ & $99.5 \pm 70.1$ & $113.2 \pm 55.9$ & $77.7 \pm 28.3$ & $\begin{array}{r}140.2 \pm \\
4.9\end{array}$ & $\begin{array}{r}189.7 \pm \\
14.2\end{array}$ & $162.4 \pm 18.7$ \\
\hline$\% \Delta$ & & $\downarrow 50.5 \%$ & $\uparrow 13.7 \%$ & $\downarrow 31.4 \%$ & $\uparrow 80.4 \%$ & $\uparrow 35.3 \%$ & $\downarrow 14.3 \%$ \\
\hline \multicolumn{8}{|l|}{ All patients } \\
\hline Mean \pm SD & $276.4 \pm 215.6$ & $506.5 \pm 658.9$ & $\begin{array}{c}1133.1 \pm \\
2352.0\end{array}$ & $\begin{array}{c}1951.0 \pm \\
3833.2\end{array}$ & $\begin{array}{c}250.3 \pm \\
382.8\end{array}$ & $\begin{array}{c}189.6 \pm \\
368.6\end{array}$ & \\
\hline$\% \Delta$ & & $\uparrow 82.2 \%$ & $\uparrow 123.7 \%$ & $\uparrow 72.2 \%$ & $\downarrow 87.2 \%$ & $\downarrow 24.2 \%$ & \\
\hline $\mathrm{N}$ & & 15 & 15 & 15 & 8 & 7 & \\
\hline
\end{tabular}

Abbreviation: B, boy; G, girl; SD, standard deviation; y, years. 


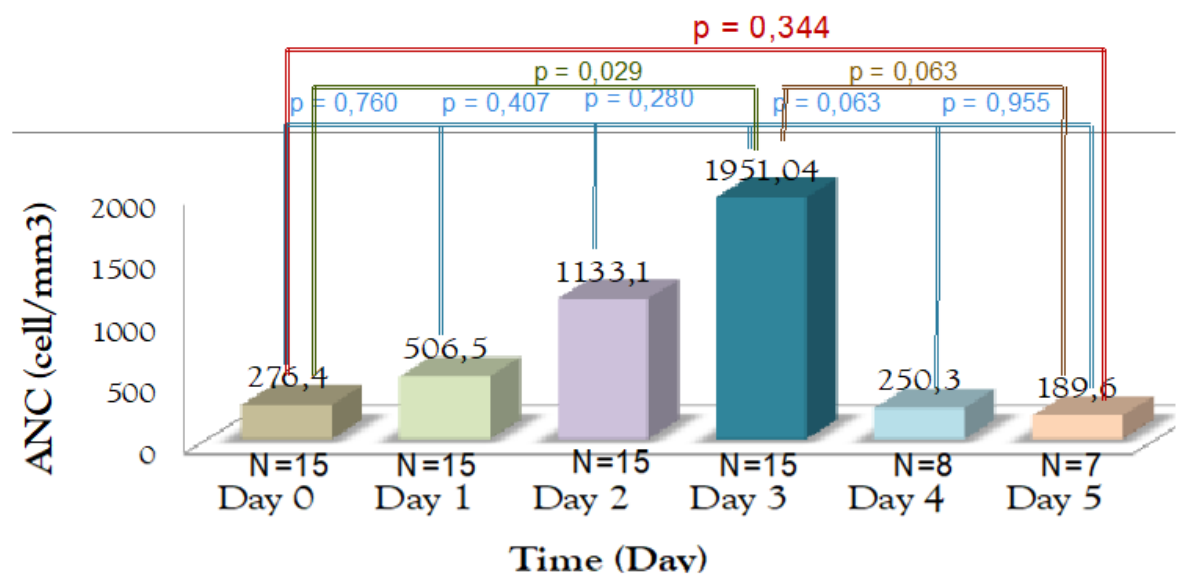

Fig. 2. Mean ANC levels per day.

Filgrastim was used in this study to correct and reverse neutropenia. Filgrastim is a 175-amino acid recombinant protein expressed in Escherichia coli. The filgrastim peptide has the same amino acid sequence as endogenous human G-CSF with the exception that the backbone of the molecule is not glycosylated and the $\mathrm{N}$ terminus is a methionine (Neumann \& Foote 2012, Holland \& Gallin 2015). Filgrastim is a late precursor in the cells maturation, in which it binds to GCSF receptor. The binding of filgrastim with GCSF's surface receptor on the haemopoietic cell is activated by phosphorylation of JAK2 and STAT molecules, a complex series of biochemical reactions by which the message is transmitted to the nucleus. The signal may activate pathways that cause the cell to enter cell cycle (replicate), differentiate, maintain viability (inhibition of apoptosis) or increase functional activity (e.g. enhancement of bacterial cell killing by neutrophils) (Dale et al 2013, Mehta \& Hoffbrand 2014).

Table 2 shows that the ANC level decreased almost $50 \%$ within 24 hours after the last dose of filgrastim. These observations are consistent with those of previous report. Upon discontinuation of G-CSF, ANC decreases by $50 \%$ within 1 to 2 days and returns to pretreatment levels within 1 week; WBC counts return to normal range in 4 to 7 days (UpToDate 2016).

Increases in ANC levels on days 1 to 5 has been hypothesized to be margination of the neutrophils to endothelial cells. The subsequent increase in circulating neutrophils may be caused by the release of mature neutrophils from the reserve pool of postmitotic mature myelocytes to complete the maturation cycle (Bekkering \& Torensma 2013). This cycle takes approximately 1 day, and the average time for a neutrophil to migrate from the reserve pool to the blood is about 10 days (Sieff 2016). Therefore, the increasing trough 24-hour
ANC level and the larger response on day 3 were probably caused by a combination of increased doserelated stimulation of myeloblast production in response to filgrastim; more rapid migration of mature neutrophils from the storage pool to the systemic circulation (since filgrastim is known to accelerate the release of peripheral blood progenitor cells into the circulation) (Molineux 2011, Welte 2012).

Pharmacokinetics were linear at day 1 to 3 , an increase dose of filgrastim resulted in a less functional proportional increase in ANC levels. However, the ANC levels were lower on day 4 to 5 compared with day 3. This may have been caused by a decrease in bioavailability, an increase in clearance, an increase in the volume of distribution or a combination of these factors. The changes in pharmacokinetic variables between day 3 and day 5 may be related to an increase in neutrophil mass by the fifth dosing day. One possibility is endocytosis by surface of G-CSF receptors. The decrease in plasma filgrastim concentration (and hence the increase in apparent clearance) may, therefore, result from the filgrastimdriven increase in the number of neutrophils and neutrophil precursors. Theoretically, at least, nonreceptor-dependent, neutrophil-mediated, accelerated filgrastim clearance may also contribute. These observations point to a negative feed-back mechanism inversely linking the numbers of neutrophils and serum G-CSF levels to limit the number of neutrophils in normal and disease states (Sieff 2016).

The presence of endogenous growth factor of individual number, as well as response cells stem which also are individually, lead to different results and also are individually between patients who received filgrastim therapy, so that only $53 \%$ of patients achieved a therapeutic target for JNA $=1000$ cells $/ \mathrm{mm}^{3}$ after 
administering filgrastim for 3-5 days. Nonetheless, these results need to be taken with caution in view of the limitations found: diverse populations and chemotherapy regimens. It is necessary to design further trials appropriately, well-powered for significant clinical outcomes and focused on high-risk patients. In addition, it is important to evaluate the cost-effectiveness of these agents in established febrile neutropenia.

\section{CONCLUSION}

Filgrastim therapy with dose of $10 \mu \mathrm{g} / \mathrm{kgBW}$ for 3 to 5 day has been able to reach the therapeutic target of $53 \%$ in acute leukemia children with neutropenia. The increased levels of ANC maximum was reached on the third day with increased levels of 9.5 fold.

\section{REFERENCES}

Bekkering S, Torensma R (2013). another look at the life of a neutrophil. World Journal of Hematology 2, 44-58

Bracci L, Schiavoni G, Sistigu A, Belardelli F (2014). Immune-based mechanisms of cytotoxic chemotherapy: implications for the design of novel and rationale-based combined treatments against cancer, A Review. Cell Death and Differentiation 21, $15-25$

Crawford J, Caserta C, Rolla F (2010). Hematopoietic growth factors: ESMO clinical practice guideline for the applications. Annals of Oncology 21, 248-51

Crawford J, Glaspy JA, Stoller RG, Tomita DK, Vincent ME, McGuire BW, Ozer H (2005). Final results of a placebo-controlled study of filgrastim in small-cell lung cancer: Exploration of risk factors for febrile neutropenia. Supprotive Cancer Therapy 3, 3646

Dalal S, Zhukovsky DS (2006). Pathophysiology and management of fever. Journal of Supportive Oncology 4, 9-16

Dale DC, Quinton LJ, Nelson S (2013). Colonystimulating factors for prevention and treatment of neutropenia and infection diseases. In: The neutrophils new outlook for old cells. 3rd Ed. US, Imperial College Press, p 399-417

Ghalaut PS, Sen R, Dixit G (2008). Role of Granulocyte Colony Stimulating Factor (G-CSF) in chemotherapy induced neutropenia. Journal Association Of Physicians India 56, 942-44

Hansen Molgaard L, Mottonen M, Glosli H, Jonmundsson GK, Abrahamsson J, Hasle H (2010). Early and treatment-related deaths in childhood acute myeloid leukaemia in the Nordic countries: 19842003. British Journal of Haematology 151, 447-59
Holland SM, Gallin JI (2015). Disorder of granulocytes and monocytes, In: Harrison's Principles of Internal Medicine. 19th ed. US, McGraw-Hill Companies, Inc, p. 413-423

Lyman GH, Abella E, Pettengell R (2014). Risk factors for febrile neutropenia among patients with cancer receiving chemotherapy: A systematic review. Critical Reviews in Oncology/Hematology 90, 190-199

Lyman GH, Dale DC, Culakova E, Poniewuerski MS, Wolff DA, Kuderer NM, Huang M, Crawford J (2013). The impact of the granulocyte colonystimulating factor on chemotherapy dose intensity and cancer survival: a systematic review and meta-analysis of randomized controlled trials. Annals of Oncology. Oxford University Press on behalf of the European Society for Medical Oncology 00, 1-10

Mehta AB, Hoffbrand AV (2014). Haemopoiesis: physiology and pathology, In: Haematology at a Glance. 4th Ed. UK, Wiley Blackwell, p 10-13

Mitchell S, Li Xiaoyan, Woods Matthew, Garcia J, Massey Hebard K, Barron R, Samuel M (2016). Comparative effectiveness of granulocyte colonystimulating factors to prevent febrile neutropenia and related complications in cancer patients in clinical practice: A systematic review. Journal of Oncology Pharmacy Practice. SagePub UK 0, 1-15

Molineux G (2011). Granulocyte colony-stimulating factors, In Lyman GH, Dale DC Hematopoietic Growth Factors in Oncology vol. 157. New York, Springer, p 33-54

Neumann TA, Foote M (2012). The safety profile of filgrastim and pegfilgrastim In: Twety years of GCSF, milestone in drug therapy. Springer, p 395-408

Permono B, Sutaryo, Ugreseno IDG, Windiastuti E, Abdulsalam M (2010). Leukemia akut, In: Buku ajar hematologi-onkologi anak cetakan ketiga. Badan Penerbit Ikatan Dokter Anak Indonesia, p 236-47

Pertiwi NMI, Niruri R, Ariawati K (2013). Gangguan hematologi akibat kemoterapi pada anak dengan leukemia limfositik akut di Rumah Sakit Umum Pusat Sanglah. Jurnal Farmasi Udayana, 59-61

Rodriguez ZN, Tordecilla CJ, Campbell BM, Joannon SP, Rizzardini LC, Soto AV, Verdugo LP (2005). Usefulness of G-CSF in pediatric high risk cancer patients with fever and neutropenia. Revista Chilena de Infectologia 22, 223-27

Rosary HAS (2010). Penggunaan granulocyte colony stimulating factor pada pasien tumor padat yang mengalami neutropenia. Sari Pediatri 11, 428-33

Scholz M, Schirm S, Wetzler M, Engel C, Loeffler M (2012). Pharmacokonetic and -dynamic Modelling of G-CSF Derivates in Humans. Theoretical Biology and Medical Modelling, BioMed Central 9 Suppl 32, 1-28

Sieff CA (2016). Regulation of Myelopoiesis. UpToDate Wolter Kluwer, 1-35 
Sudewi N, Alan R, Endang W (2007). Kejadian demam neutropenia pada keganasan. Sari Pediatri 8, S68-72

Tubergen DG, Bleyer A, Ritchey AK, Friehling E (2016). The Leukemias In: Kliegman RM, Stanton BF, St. Geme III JW, Schor NF. Nelson Textbook of Pediatrics. 20th Ed. Canada, Elsevier, Inc, p 2437-44

UpToDate (2016). Filgastrim: Pediatric Drug Information. UpToDate. Wolters Kluwer, 1-9

Velasco RP (2010). Review of granulocyte-stimulating factors in the treatment of established febrile nuetropenia. Journal of Oncology Pharmacy Practice 17, 225-32

Welte K (2012). Discovery of G-CSF and early clinical studies. In: G. Molineux, Foote M., Arvedson, E., (eds). Twenty Years of G-CSF Clinical and Nonclinical Discoveries, Milestones in Drug Therapy. Mirogojska, University Hospital for Infectious Disease "Dr. Fran Mihaljevic", p 15-24 